Lorenzana, J. A., \& Soriano, C. R. R. (2021). Introduction: the dynamics of digital communication in the Philippines: legacies and potentials. Media International Australia, 179(1), 3-8.

\title{
Introduction: the dynamics of digital communication in the Philippines: legacies and potentials
}

\author{
Jozon A Lorenzana \& Cheryll Ruth R Soriano
}

In the early 2000s, Filipino scholars explored how mobile communication and the staggering popularity of texting technology allowed Filipinos to express themselves in novel ways, enact forms of intimacy with family members and strangers (Parreñas, 2001; Pertierra, 2005; Pertierra et al., 2002) or participate in political mobilisation (Rafael, 2003). On the contrary, Internet research in its earlier formations focused on the relationships between information and communication technology (ICT) and development, with studies exploring the promises of digital communication for better governance, service delivery and participation amid questions of access inequalities (e.g. see Alampay, 2006). Perhaps a thread that ties these two earlier bodies of work is the anticipation of the possibilities that digital media can bring for individual expression, harnessing human relation- ships, accessing economic opportunity and reconfiguring relationships between citizens and the state. However, as Raul Pertierra (2009) lamented,

modern technologies were introduced into the country soon after their discovery but despite their transformative potential there was very little change in the basic structures of society . . . because these technologies did not enter into the everyday life of most Filipinos. (pp. 36, 38)

An agenda of hope is expected in a nation rife with high levels of poverty and inequality, and low levels of trust in state institutions, but which was also experiencing heightened informational flows and new aspirations along with exposure to emancipatory discourses surrounding technology.

In the era of mobile Internet, platforms and convergent digital communication, and along with the increasing penetration of digital media in the everyday life of most Filipinos, multiple and interconnected social, economic, cultural and political relations which align with spectacular developments in digital technology currently unfold. From texting technology, we now see Filipinos engaged in a communicative ecology of practices and relations that move fluidly from one device and platform to another. As Filipinos achieved greater geographical and social mobility, digital communication became more important than ever to cater to the sharp rise in informational, economic, social and political demands of citizens. This growing consumption capacity, along with the availability of low-cost devices and Internet promotions by telecommunications and Internet companies which cater to a broad range of income groups, helped drive the digital communication boom, with the Philippines now considered one of the largest markets for platforms such as Facebook and YouTube and consistently topping the world in terms of time spent per day on social media ( $\mathrm{We}$ 
Are Social, 2020). We are also active users of dating apps (Labor, 2020), and the fastest growing freelancing market in the world in 2020 (Payoneer, 2020). The continued growth of inter- active applications reconfigures the Filipino consumer base as active and dynamic publics choosing from a range of communicative options and relational possibilities (Madianou and Miller, 2012) and as creators of content seeking opportunities for heightened self-expression and recognition.

Global digital information flows appear to be transforming Philippine society as engagements with digital technologies recast family relationships, civic consciousness, work and professional life, and forms of social organisation. Against a backdrop of growing digital communication research in the Philippines, responses to these rapid developments and perceptions about their gains and repercussions have at best been contradictory and fragmented, with some highlighting exploitative, disruptive or empowering implications. The question asked by Pertierra (2009) looms more than a decade hence: how has digital communication transformed the deeper structures of Philippine society, and to what ends? Pertierra's fundamental question about digital media and social transformation informs the studies in this special collection. The authors' analyses of digital media's presence and significance in the various domains of entertainment, everyday politics, intimacy, labour and news media also reflect the possible articulations of the socio-technical dynamic.

The following articles demonstrate manifestations and dynamics of capitalist modernity. We identify three overlapping themes which indicate how the affordances and uses of digital media contribute to the accumulation of various forms of capital and the acceleration of social processes that create new and reinforce existing social inequalities (Fuchs, 2014; Rosa, 2014). The ethnographic and qualitative nature of the studies provides nuances to the simultaneous possibilities for liberation and exploitation (Jordan, 2015) amid digital media's embedding in everyday life. Each theme characterises a socio-technical dynamic that indicates continuities, contradictions and changes in society.

\section{Material, social and structural conditions of digital media engagements}

Digital media uses, practices and experiences are rooted in pre-existing social and cultural formations, economic structures and political systems (Athique, 2019). Even as the digital media environment presents various possibilities for action and social relations, uneven infrastructure and material conditions shape people's engagements with digital media. This is salient in Toyama's (2011) argument that technologies are not transformative or democratising in themselves, but rather, they amplify human forces along with existing inequalities and missing institutional capaci- ties. In this issue, Cecilia Uy-Tioco and Jason Cabañes (2021) examine glocal intimacies defined as 'how mobile technologies normalise and intensify the entanglement of people's relationships of closeness with the constantly shifting and negotiated flows between global modernity and local everyday life'. Comparing experiences of glocal intimacy across income groups, they demonstrate that economic status continues to shape not only access to digital infrastructure and its benefits but also the enactment of mediated 
relationships. Furthermore, their study illustrates how the services and digital infrastructure created by a duopoly in the Philippine telecommunication industry reflect and reinforce differential digital access according to socio-economic class. A similar situation of how opportunities afforded by access to digital media are shaped by social structure and political economy is evident in Cheryll Soriano's (2021) analysis of emerging forms of brokerage in digital labour. Based on a 4-year digital ethnography on online freelancing and platform labour in the Philippines, Soriano's article highlights the layers of brokerage that involve global labour platforms and informal networks of local workers and agents that together mediate between global and local capital. She argues that labour platforms may be seen as providing the important ideological foundation for organising labour in this economy, but localised labour regimes construct the dynamics of the platform labour experience for local workers. These brokerage mechanisms may appear to make platform labour palatable and facilitate local workers' opportunities in the global platform labour economy; however, they also reinforce its oppressive conditions while facilitating mechanisms for survival. The terms of work and relationship on digital platforms reflect the competitive and unequal dynamics of digital capitalism (Fuchs, 2014).

\section{Unleashing the potentials of networked communication and publics}

While the experience of digital media in the Philippines shows contradictory tendencies stemming from economic arrangements, the affordances of digital media, especially social media, present new potentials in everyday life. The articles in the special collection indicate the social and political possibilities of networked communication and publics (Highfield, 2016; Papacharissi, 2015). Focusing on everyday politics of reputation, Jozon Lorenzana (2021) examines mediated scandals which unfold on social media. Lorenzana analyses how parties use social media and identifies the digital media affordances at work in each phase of a scandal. The Philippine examples show that the use of social media does not only accelerate and intensify public condemnation by allowing more people to participate, but also enables actors to counter allegations and protect their reputation. Lorenzana's analysis of mediated scandals draws attention to the harmful possibility of dis- cursive violence that characterises everyday politics of reputation on social media.

Conversely, the relative anonymity afforded by social media can transform potentially scandalous activities into a basis of sociality. Ruepert Cao (2021) explores the dynamics of Alter Community, a group of Filipino gay men who share amateur pornography on Twitter. By immersing in the world of Alter, Cao finds that the production and consumption of pornographic videos relate to the performance of hyper masculinity which Filipino gay men use to mark boundaries of their identity. While the practice creates a sense of belonging among marginalised gay men, Cao also argues that the technical affordances of Twitter, which include its algorithms, contribute to the ghettoisation of the Alter Community. Hence, the study shows how social media platforms simultaneously configure the possibilities and limits of networked publics. 


\section{Convertibility of capitals and emergence of competencies}

Finally, the uses of digital media and their embedding in various domains illustrate the simultaneous process of generating networked publics and the convertibility of capitals across domains. Combining historical and ethnographic perspectives, Anna Pertierra looks at transformations in the Philippine television industry where entertaining the public has become 'entertainment publics'. She argues that prominent mass media producers have largely succeeded in co-opting or grafting digital media celebrity and viral social media into existing broadcasting ecologies. Social media provide venues for more engagement between celebrities and audiences which cultivate loyalty that can be carried over in the realm of politics. Pertierra's study tells us how social capital can be converted into political capital through social media engagements.

The convertibility of capitals in a digital media environment has implications for other sectors of the media. With access to content production afforded by digital platforms, actors with varying interests and relevant communication skills have participated in the news media economy as bloggers, citizen journalists or influencers (Ong and Cabañes, 2018). Like their counterparts elsewhere, journalists in the Philippines have responded to the ways social media complicate the practice of journalism. Pauline Estella (2021) investigates how competencies of Filipino journalists have evolved in light of the challenges of digital populism and de-legitimation of journalists. Drawing from surveys and interviews, Estella develops the concept of journalistic competency that com- bines technological adeptness, critical reflexivity, mobile reporting, awareness of Global South conditions and commitment to the public role of journalism. Estella's study points to the emer- gence of competencies or new forms of cultural capital that are needed to navigate a competitive and unpredictable digital media environment.

Indeed, as other papers also suggest (e.g. building new skills for a digital labour platform (Soriano, 2021), mastering the analytics of Twitter (Cao, 2021), countering narratives on social media (Lorenzana, 2021)), the integration of digital media in aspects of everyday life generates situations and structures that require new abilities and predispositions. Thus, our assessment of the experience of digital media in the Philippines still points to the accumulation of capitals and their conversion, processes which are consistent with capitalist modernity. Going back to Raul Pertierra's question on how Philippine society is transforming with digital media, our themes suggest the continuities of social and economic structures, contradictions between opportunity and constraint in social and economic activities, and changes in the ways digital media facilitate the accumulation of capitals that paradoxically feeds into inequality.

In this issue, we considered the Philippines as an unbounded and fluid entity involving the social relations of Filipinos in and outside the Philippines, and with practices 
taking place in digital spaces that converge with the global. It is also through these global ties that this special issue was birthed and crystallised. From the Digital Transactions in Asia International Conference held in Manila in 2018 and through the generous support of the University of Queensland and former and current editors of Media International Australia, Adrian Athique and Matthew Allen, the Philippinesfocused papers presented in that conference, along with new contributions, now form the pieces comprising this issue. We are very grateful to them and to the authors for facilitating this timely scholarly conversation. The special issue also benefitted from scholars located in the Philippines and elsewhere who shared their expertise and time during a challenging period and whose contributions have substantially enriched this issue.

As the papers in this collection show, individual practices emerge with their collective ripples at the community, national and global levels. Amid the spread of global networks, platforms, supply chains and transborder relations, our special issue also signals that examining the emplacement of global digital cultures in the local is significant in grasping its transformative impacts. We therefore hope that this special issue on the dynamics of digital communication in the Philippines makes a contribution in our efforts to understand the trajectory of global transformations engendered by digital communication.

\section{References}

Alampay EA (2006) Beyond access to ICTs: measuring capabilities in the information society. International Journal of Education and Development Using Information and Communication Technology 2(3): 4-22.

Athique A (2019) Digital emporiums: platform capitalism in India. Media Industries 6: 205 .

Cao RJD (2021) Amateur porn in Filipino Twitter Alter community: architecture, affordances, and logics of commodification and ghettoization. Media International Australia 179(1): 52-65.

Estella PG (2021) Digital populism, digital newswork, and the concept of journalistic competence: the Philippine condition. Media International Australia 179(1): 80-95.

Fuchs C (2014) Digital prosumption labour on social media in the context of the capitalist regime of time. Time \& Society 23(1): 97-123.

Highfield T (2016) Social Media and Everyday Politics. Malden, MA: Polity Press.

Jordan T (2015) Information Politics: Liberation and Exploitation in the Digital Society. London: Pluto Press. 
Labor J (2020) Mobile sexuality: presentations of young Filipinos in dating apps. Plaridel: A Philippine Journal of Communication, Media, and Society 17(1): 1-32.

Lorenzana JA (2021) The potency of digital media: group chats and mediated scandals in the Philippines. Media International Australia 179(1): 38-51.

Madianou M and Miller D (2012) Migration and New Media: Transnational Families and Polymedia. London: Routledge.

Ong JC and Cabañes JVA (2018) Architects of Networked Disinformation: Behind the Scenes of Troll Accounts and Fake News Production in the Philippines. Manila, Philippines: Newton Tech4Dev Network.

Papacharissi Z (2015) Affective Publics: Sentiment, Technology, and Politics. New York: Oxford University Press.

Parreñas R (2001) Mothering from a distance: emotions, gender, and intergenerational relations in Filipino transnational families. Feminist Studies 27(2): 361-390.

Payoneer (2020) Freelancing in 2020: an abundance of opportunities. Available at: https://pubs.payooneer.com/docs/2020-gig-economy-index.pdf (accessed 10 March 2021)

Pertierra AC (2021) Entertainment publics in the Philippines. Media International Australia 179(1): 66-79.

Pertierra R (2005) Mobile phones, identity and discursive intimacy. Human Technology: An Interdisciplinary Journal on Humans in ICT Environments 1: 23-44.

Pertierra R (2009) Technologies of transformation: The end of the social or the birth in the cyber network. In: Alampay E (ed.) Living the Information Society in Asia. Singapore: Institute of Southeast Asian Studies, pp. 36-56.

Pertierra R, Ugarte E, Pinggol A, et al. (2002) Txt-ing Selves: Cellphones and Philippine Modernity. Manila, Philippines: De La Salle University Press.

Rafael V (2003) The cell phone and the crowd: messianic politics in the contemporary Philippines. UCLA: Center for Southeast Asian Studies. Available at: https://escholarship.org/uc/item/5t1376v0 (accessed 28 February 2021)

Rosa H (2014) From work-life to work-age balance? Acceleration, alienation, and appropriation at the work- place. In: Korunka $\mathrm{C}$ and Hoonakker $\mathrm{P}$ (eds) The Impact of ICT on Quality of Working Life. Dordrecht: Springer, pp. 43-61.

Soriano CR (2021) Digital labour in the Philippines: emerging forms of brokerage. Media International Australia 179(1): 23-37.

Toyama K (2011) Technology as amplifier in international development. In: Grudin J 
(ed.) Proceedings of the 2011 iConference on: iConference'11. New York: ACM Press, pp. $75-82$.

Uy-Tioco CS and Cabañes JVA (2021) Glocal intimacies and the contradictions of mobile media access in the Philippines. Media International Australia 179(1): 9-22.

We Are Social (2020) Digital in 2020. Available at: https://wearesocial.com/digital2020 (accessed 28 February 2021). 